\title{
Towards Constraining Glacial Isostatic Adjustment in Greenland Using ICESat and GPS Observations
}

Nielsen, Karina; Sørensen, Louise Sandberg; Khan, Shfaqat Abbas; Spada, Giorgio; Simonsen, Sebastian Bjerregaard; Forsberg, René

Published in:

Earth on the Edge: Science for a Sustainable Planet

Publication date:

2014

Link back to DTU Orbit

Citation (APA):

Nielsen, K., Sørensen, L. S., Khan, S. A., Spada, G., Simonsen, S. B., \& Forsberg, R. (2014). Towards Constraining Glacial Isostatic Adjustment in Greenland Using ICESat and GPS Observations. In C. Rizos, \& P. Willis (Eds.), Earth on the Edge: Science for a Sustainable Planet (pp. 325-331). Springer. International Association of Geodesy Symposia Vol. 139

\section{General rights}

Copyright and moral rights for the publications made accessible in the public portal are retained by the authors and/or other copyright owners and it is a condition of accessing publications that users recognise and abide by the legal requirements associated with these rights.

- Users may download and print one copy of any publication from the public portal for the purpose of private study or research.

- You may not further distribute the material or use it for any profit-making activity or commercial gain

- You may freely distribute the URL identifying the publication in the public portal 


\title{
Towards Constraining Glacial Isostatic Adjustment in Greenland Using ICESat and GPS Observations
}

\author{
Karina Nielsen, Louise S. Sørensen, Shfaqat Abbas Khan, Giorgio Spada, \\ Sebastian B. Simonsen, and René Forsberg
}

\begin{abstract}
Constraining glacial isostatic adjustment (GIA) i.e. the Earth's viscoelastic response to past ice changes, is an important task, because GIA is a significant correction in gravitybased ice sheet mass balance estimates. Here, we investigate how temporal variations in the observed and modeled crustal displacements due to the Earth's response to ongoing ice mass changes can contribute to the process of constraining GIA. We use mass change grids of the Greenland ice sheet (GrIS) derived from NASA's high resolution Ice, Cloud and land Elevation Satellite (ICESat) data in three overlapping time spans covering the period 2004-2009 to estimate temporal variations in the elastic response due to present day ice mass loss. The modeled crustal displacements (elastic + GIA) are compared with GPS time series from five permanent sites (KELY, KULU, QAQ1, THU2, and SCOR). We find, that the modeled pattern of elastic crustal displacements shows pronounced variation during the observation period, where an increase in elastic displacement is found at the northwest coast of Greenland, while a decrease is found at the southeast coast. This pattern of temporal changes is supported by the GPS observations. We find, that the temporal behavior of the ICESat-based modeled elastic response agrees well with the GPS observations at the sites KELY, QAQ1, and SCOR. This suggests, that our elastic models are able to resolve the temporal changes in the observed uplift, which indicates that the elastic uplift models are reliable at these sites. Therefore, we conclude that these sites are useful for constraining GIA.
\end{abstract}

Keywords

GIA $・$ GPS $・$ ICESat $・$ Elastic uplift $・$ Greenland

\section{Introduction}

The Gravity Recovery and Climate Experiment (GRACE) satellites measure the combined gravity change, resulting from e.g. present day ice mass changes and mass movements

K. Nielsen $(\bowtie) \cdot$ S.A Khan

Department of Geodesy, DTU Space - National Space Institute, Technical University of Denmark, 2800 Kgs. Lyngby, Denmark

e-mail: karni@space.dtu.dk

L.S. Sørensen • R. Forsberg

Department of Geodynamic, DTU Space - National Space Institute,

Technical University of Denmark, 2800 Kgs. Lyngby, Denmark in the mantle due to GIA. Therefore, reliable estimates of GIA are an important part of ice sheet mass balance studies based on GRACE observations. The currently available GIA models predict quite different present day signals in ice covered regions such as Greenland and Antarctica

G. Spada

Dipartimento di Scienze di Base e Fondamenti (DiSBeF), Università di Urbino "Carlo Bo", Urbino, Italy

S.B. Simonsen

Centre for Ice and Climate, NBI, University of Copenhagen, Juliane

Maries Vej 30, 2100 Copenhagen, Denmark, and Danish Climate

Centre, DMI, Lyngbyvej 100, 2100 Copenhagen, Denmark 
because the data (indicators of past sea level, such as marine deposits, and geological evidence of ice sheet extent) used to develop the ice history are sparse in these regions. It is therefore important to constrain the GIA signal in these areas, using additional data such as GPS observations of crustal movement.

Today, several GPS stations are located along the coast of Greenland, continuously measuring the bedrock motion. This motion contains contributions from the elastic deformation of the Earth to ongoing ice mass changes, the viscoelastic response due to past glacial changes, i.e. GIA, and possibly tectonic motion. Due to considerably mass loss of the GrIS over the last decade, and associated unloading of the Earth, the elastic signal of bedrock movement is dominant, compared to the GIA signal, in large parts of the coastal areas. It is therefore important to model the present day elastic response with high resolution and precision when GPS observations are used to constrain the GIA signal. Several studies have used GPS observations to constrain GIA models, in Antarctica (Bevis et al. 2009; Thomas et al. 2011), and in Greenland (Khan et al. 2008; King et al. 2010; Spada et al. 2012). In these studies the elastic signal is subtracted from the GPS observations, to constrain the GIA signal hence relying on the accuracy of the elastic correction or its minor influence at the GPS stations. Over a period of a few decades it is reasonable to assume that the crustal response caused by GIA is constant. Hence, if the elastic response is modeled correctly we expect to find a correlation between the temporal changes in GPS rates and the modeled elastic response. This hypothesis is a way to validate the modeled elastic response, which enables us to obtain more reliable constraints on the GIA response at the GPS locations.

Here, we investigate the temporal changes in the present day elastic response caused by mass changes of the GrIS. To do so, we estimate the elastic response in three overlapping time spans 2004-2007, 2005-2008, and 2006-2009, based on mean mass change grids derived from ICESat data using the methodology described in Sørensen et al. (2011). To assess our modeled elastic response, we analyse GPS time series at five permanent stations SCOR, KULU, QAQ1, KELY and THU2. We analyze and compare the temporal changes found in the modeled elastic response and those observed by GPS. We test if this analysis improves our ability to asses the validity of the elastic signal. This will help us to identify whether the potential discrepancies between the modeled and observed present day uplift are the result of either errors in the GIA model or in the elastic model. Finally, to test the performance of GIA model estimates, which here are based on the deglaciation histories ICE-5G (Peltier 2004), ANU05 (Fleming and Lambeck 2004) and Huy2 (Simpson et al. 2009), we compare the sum of the modeled elastic uplift and present day GIA rates, with the observed uplift rates at the five GPS sites.

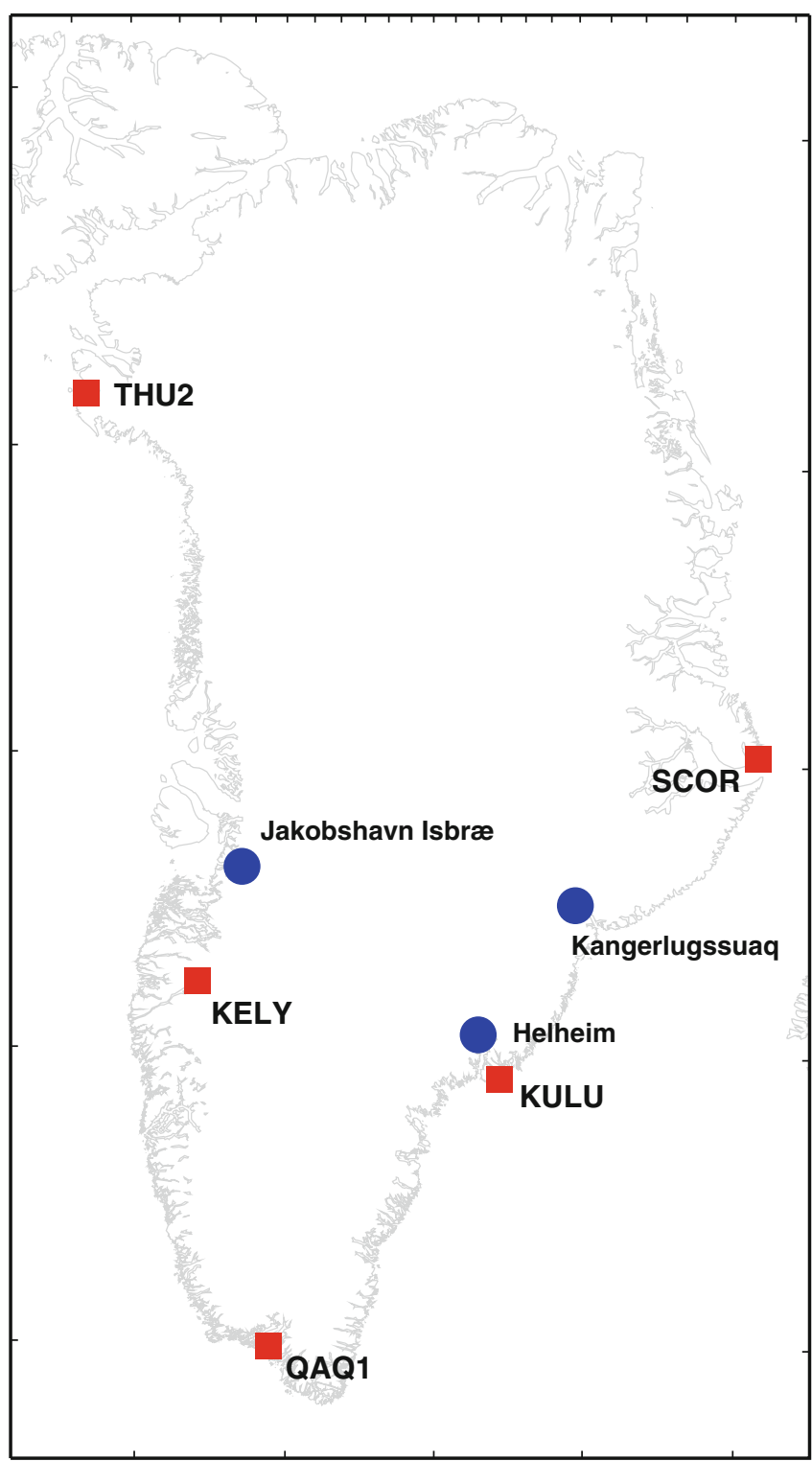

Fig. 1 Locations of the five permanent long term GPS stations, KELY, KULU, QAQ1, THU2, and SCOR indicated with red squares. The location of the three major outlet glaciers, Helheim, Kangerlussuaq and Jakobshavn are indicated with blue dots

\section{$2 \quad$ Data and Methods}

\section{$2.1 \quad$ GPS}

We analyze GPS data from five permanent stations, THU2, KELY, SCOR, KULU, and QAQ1. The locations of these are shown in Fig. 1. To estimate the site coordinates, we use the GIPSY OASIS 6.1 software package (Zumberge et al. 1997) developed at the Jet Propulsion Laboratory (JPL). As an improvement to the processing done in Khan et al. (2010a), we here use IGS repro1 satellite orbits, satellite clock parameters, and Earth orientation parameters, which are probably 


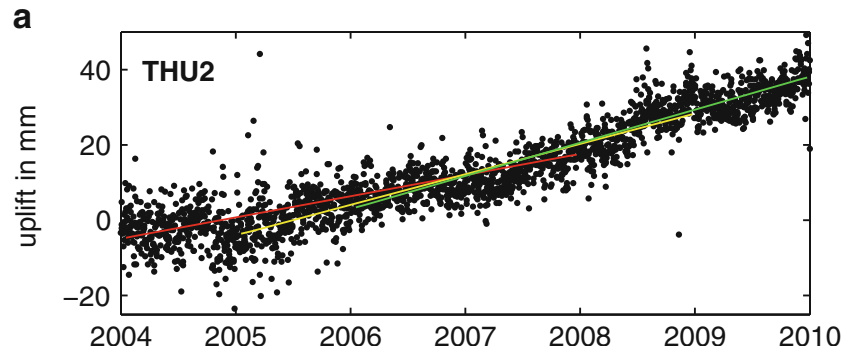

b

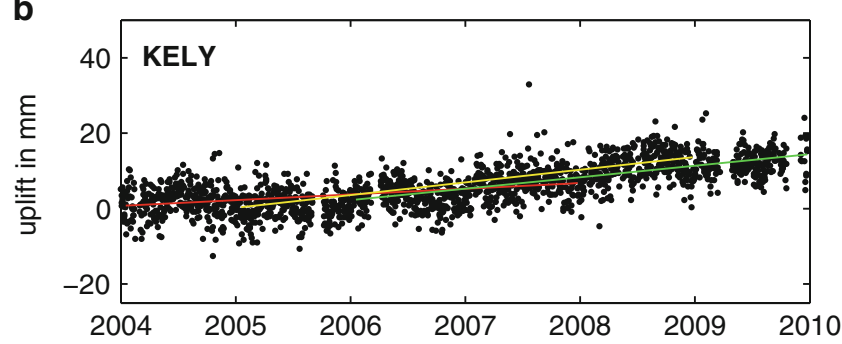

c

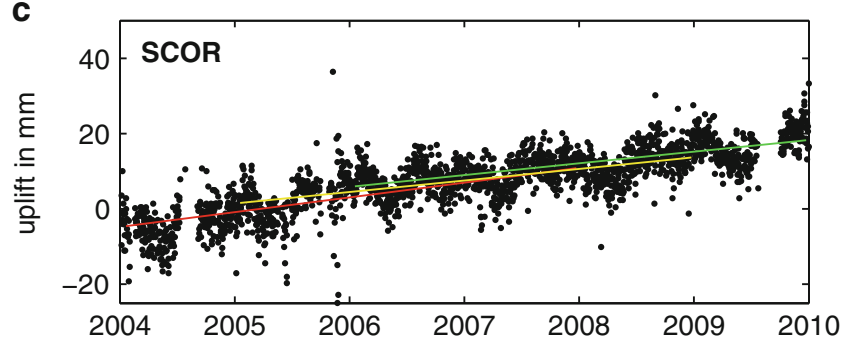

d

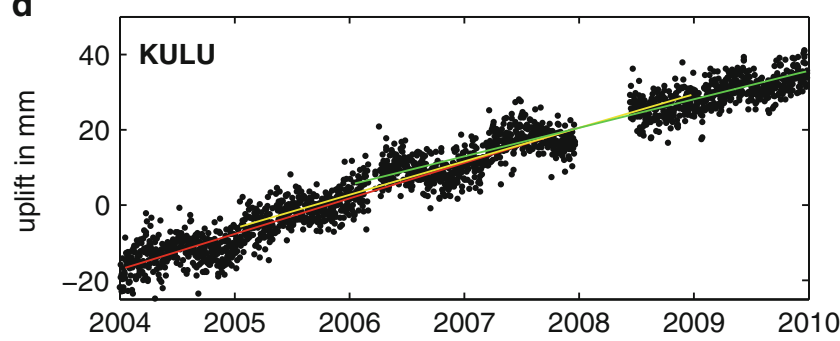

e

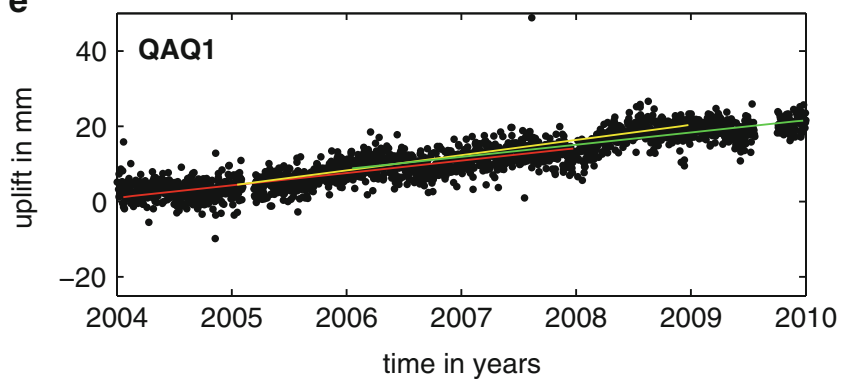

Fig. 2 Daily values of vertical positions in $m m$ at (a) THU2, (b) KELY, (c) SCOR, (d) KULU, (e) QAQ1. Each dot represents a daily solution. The red, yellow, and green curves represents the best fitting linear terms to data during 2004-2007, 2005-2008, 2006-2009, respectively

more accurate, since they represent a combined solution from several orbits processing centers (JPL, MIT, CODE and others). The repro1 products take the satellite antenna phase center offsets into account. The GPS data is processed as described in Khan et al. (2010b). The solutions are given in the Earth's centre of mass reference frame and aligned with the IGS05 frame (Altamimi et al. 2007). Figure 2 shows daily vertical GPS averages at the five sites, obtained using IGS products, after removing annual and semi-annual variations. Also shown are the best fitting trends to the data during 2004-2007 (solid red curve), 2005-2008 (solid yellow curve), and 2006-2009 (solid green curve). In the three time spans all years are inclusive.

\section{$2.2 \quad$ ICESat}

The Geoscience Laser Altimeter System (GLAS; Abshire et al. 2005) on board the ICESat satellite repeatedly measured the elevation of the ice sheets with a high accuracy in the period 2003-2009. Here, we use the data product GLA12 "Antarctic and GrIS Altimetry Data" release 31 (Zwally et al. 2010), downloaded from the National Snow and Ice Data Center. The time span of the data set used here is February 2004 to October 2009. In this analysis we leave out data from 2003 since only 1 month of data is available with the 91-day repeat cycle.

Surface elevation changes of the GrIS are derived by applying a method (M3) presented in Sørensen et al. (2011). A mean elevation change is estimated with an along-track resolution of $500 \mathrm{~m}$ by least-squares fitting of rigid planes to the ICESat measurements and assuming a constant rate of elevation change. A part of the observed elevation change is not related to mass changes such as firn compaction, ICESat inter-campaign elevation biases and the response of the bedrock to mass changes. We correct for these, and use a density model to convert the estimated elevation changes into mass changes. Both the firn compaction and density models are forced by climate data from the HIRHAM5 regional climate model (Lucas-Picher et al. 2012). The procedure of deriving mass change grids from ICESat data is described in detail in Sørensen et al. (2011). Here, we derive mean mass change grids ( $5 \mathrm{~km}$ resolution) for the GrIS in three different time spans; 2004-2007, 2005-2008, and 2006-2009. This analysis shows that ICESat data can resolve temporal mass changes of the GrIS, which was not shown in Sørensen et al. (2011), where one mean mass balance estimate was derived for the period 2003-2008.

\subsection{Modelled Crustal Movement}

The crustal displacements are a combination of the elastic response from present day mass changes and the viscoelastic effect from past ice changes occurring since the last glacial maximum. Here, we model the present day elastic movement in three overlapping time spans 2004-2007, 2005-2008, and 2006-2009, based on loading models derived from ICESat 
Table 1 Lithosphere thickness (LT) and upper and lower mantle viscosities (UMV and LMV) used in the GIA models

\begin{tabular}{llll}
\hline Earth parameter & ICE-5G & ANU05 & Huy2 \\
\hline LT $(\mathrm{km})$ & 90 & 80 & 120 \\
\hline $\mathrm{UMV}\left(\times 10^{21} \mathrm{~Pa} \mathrm{~s}\right)$ & 0.5 & 0.4 & 0.5 \\
\hline LMV $\left(\times 10^{21} \mathrm{~Pa} \mathrm{~s}\right)$ & 2.7 & 10 & 1.0 \\
\hline
\end{tabular}

These Earth model parameters are taken from Simpson et al. (2011) (Huy2) and Spada et al. (2012) (ICE-5G and ANU05)

data (see Sect. 2.2), using the regional elastic rebound (RER) method (Spada et al. 2012). The RER method follows the Green's functions methods (Farrell 1972), with load deformation coefficients (LDCs) based on an Earth model with PREM (Dziewonski and Anderson 1981) structure and given in the Earth's centre of mass reference frame. The LDCs are calculated up to harmonic degree $10^{5}$, corresponding to a spatial resolution of $0.2 \mathrm{~km}$ (see Spada et al. 2012 for details). The RER method is a high-resolution method developed specifically to capture the short wavelength components of the vertical elastic response to the current ice mass loss. The $5 \times 5 \mathrm{~km}$ ICESat mass changes grid cells are converted in to discs (radius of $0.025^{\circ}$ ) with a matching area, and a convolution is performed between the elastic Green's functions and each disc-shaped mass element in the loading model.

The GIA estimates used here, are taken from the literature, with the ICE-5G and ANU05 results coming from Spada et al. (2012) and the Huy2 result coming from Simpson et al. (2011). The Huy2 is actually a regional deglaciation model for Greenland. In the study by Simpson et al. (2011), this is accounted for by using the ICE-5G deglaciation model for the non-Greenland component of the ice model. The GIA estimates are based on a radially stratified, selfgravitating Earth model. The Huy 2 estimates assume a compressible Earth model, while an incompressible Earth model is assumed in the numerical implementation, performed using the Program SELEN (Spada and Stocchi 2007), of the ICE-5G and ANU05 models. The radial viscosity structure are approximated by an elastic lithosphere, a viscous upper and lower mantle (see Table 1). All GIA estimates are given in the Earth's centre of mass reference frame.

\section{$3 \quad$ Results}

The modeled present day elastic response based on the RER method, is illustrated in Fig. 3 for each of the three time spans. The result presented in Fig. 3a covers the time span 2004-2007, and shows pronounced uplift along the southeast coast, with a maximum of $32 \mathrm{~mm} /$ year near the Kangerlussuaq glacier (location indicated in Fig. 1). Strong modeled uplift signals are also observed near Jakobshavn Isbræ (location indicated in Fig. 1) and along the northwest coast. As time evolves, depicted in Fig. 3b, c we see, that the
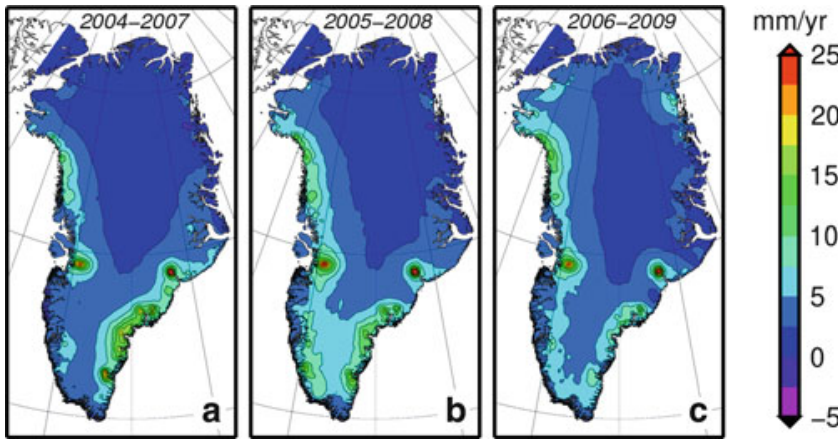

Fig. 3 Modelled elastic uplift as a function of time. The applied loading models are based on ICESat data as described in Sørensen et al. (2011). (a) shows the spatial distribution of elastic uplift, based on the mass changes between 2004 and 2007, (b) between 2005 and 2008, and (c) between 2005 and 2008

modeled uplift pattern gradually changes, and that the area of pronounced uplift moves from the southeast coast towards the northwest and north coasts of Greenland. In Fig. 3b, which covers the time span 2005-2008, the signal intensifies along the west coast and weakens along the southeast coast. In Fig. 3c, which covers the time span 2006-2009 an increase in modeled elastic uplift along the north and northeast coasts of Greenland is also observed. Over the entire time span 2004-2009 we see from Fig. 2, that the east coast GPS sites SCOR and KULU observe a decrease in uplift rates, while the west coast sites KELY and THU2 observe an increase. The site QAQ1 located at the southern tip of Greenland shows only little change in uplift rates. Figure 4 shows a comparison between the observed and modeled (elastic + GIA) uplift rates in each of the three time spans, at the five GPS sites. For comparison the modeled elastic uplift rate is indicated with a cross. At the sites KELY, QAQ1, and SCOR, a combination of modeled elastic and at least one of the GIA-induced present day uplift rates lies within the error bars $( \pm 2 \sigma)$ of the GPS rates in all time spans, with RER+Huy2, RER, and RER+Huy2 as the best models, respectively. At the site THU2 we observe a fit within the error bars at the first time span with ICE-5G+RER as the best model, while at KULU none of the models fit within the error bars of the GPS rates. At all sites, we notice, that the modeled elastic and observed response follow the same temporal change (indicated by the dotted lines), though at the site THU2 the offset between the modeled elastic rates and the GPS rates shows a slightly larger variation.

\section{Discussion and Conclusion}

The modeled elastic response due to ice mass changes in Greenland (see Fig. 3) shows pronounced spatial variability over the relatively short observation period of ICESat. This is the first time that the temporal changes of the entire GrIS 


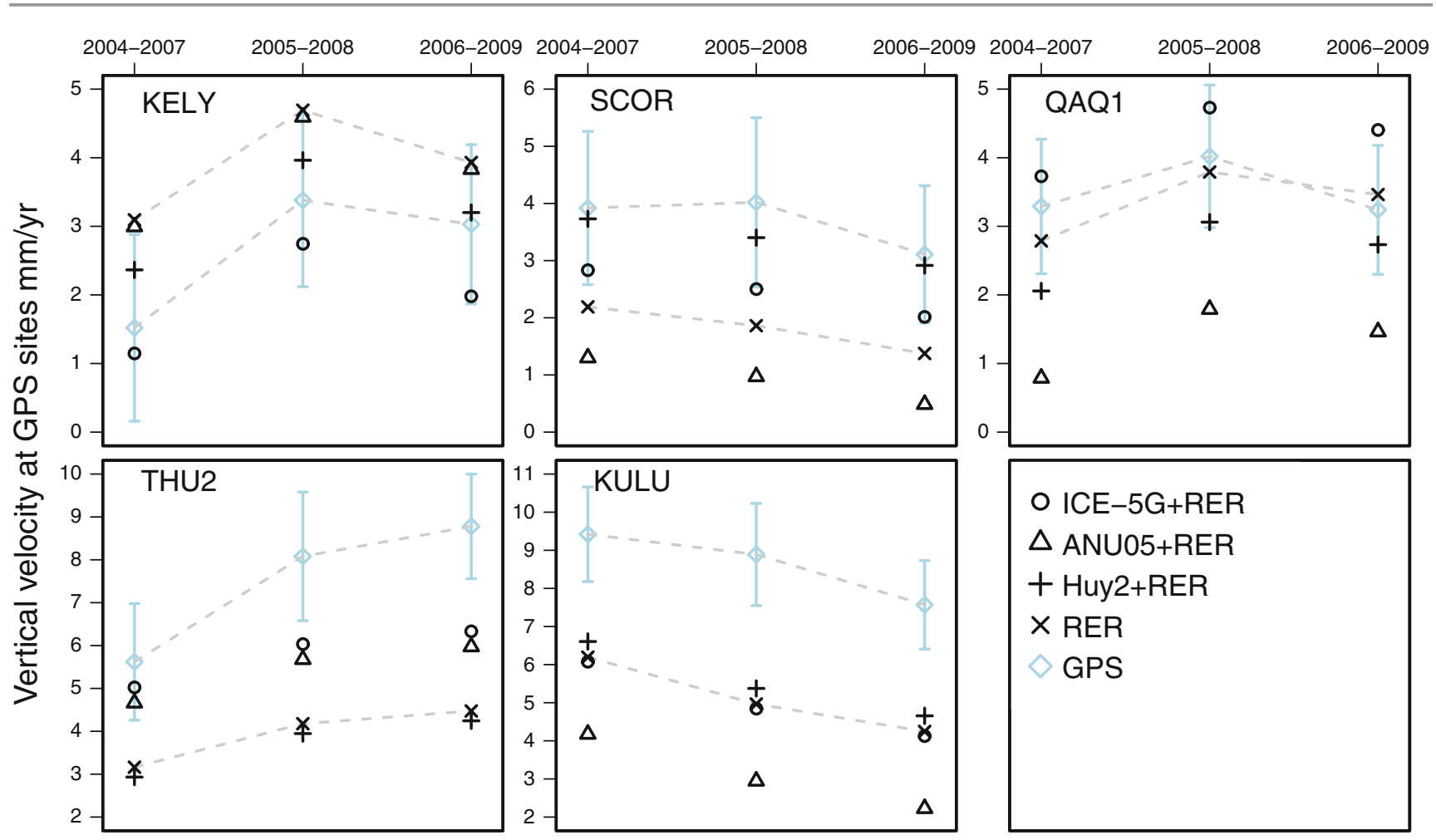

Fig. 4 Observed and modeled vertical velocities in the three time spans 2004-2007, 2005-2008, 2006-2009, at the permanent long term GPS stations KELY, KULU, QAQ1, THU2, and SCOR. The GPS rate indicated with light blue color, where the error bar represents $2 \sigma$. The modeled uplift rate, depicted with black symbols, is composed of an elastic (RER) contribution (caused by present day mass changes), and

based on ICESat data have been used in a comparison with GPS measurements. We observe an increase in mass loss and hence also elastic uplift along the west and northwest coasts of Greenland, and a decrease along the southeast coast, considering the entire observation period 2004-2009. This change in mass loss pattern agrees well with observations made by others, based on e.g. GRACE data (Khan et al. 2010a; Chen et al. 2011; Schrama et al. 2011).

We find that the GPS uplift rates show a similar behaviour to that of the modeled elastic response, with an increase in uplift rates at sites located at the west coast of Greenland, and a decrease at sites located at the southeast coast during the observation period.

Comparing the modeled (GIA + RER) and observed present day uplift rates at the five GPS sites (see Fig.4), a good fit is found at the sites KELY, QAQ1, and SCOR, where one or more of the models fit within the error bars of the GPS. At these sites the modeled elastic and the observed uplift rates follow the same temporal behavior (see Fig. 4). This demonstrates, that the elastic uplift models are able to resolve the temporal changes observed at the GPS sites and indicates that the elastic signal has been captured correctly. a GIA contribution (caused by past mass changes). Here the three GIA models ICE-5G, ANU05, and Huy2 have been considered. The dotted lines are added to better enlighten the comparison between observed and modeled uplift rates. Notice that the scale is different for the individual sites

At the site KULU none of the models (GIA + RER) fit the GPS rates, despite the nearly constant offset between the modeled elastic and observed uplift rates (see Fig. 4). Based on these considerations alone, it is not possible to determine whether these discrepancies between the modeled and observed uplift, are a result of errors in the GIA models or a bias in the mass change estimate, which leads to a bias in the elastic uplift signal. ICESat data has a lower resolution in the southern part of Greenland, where the tracks are separated with up to $30 \mathrm{~km}$, hence ICESat might not be able to capture the entire mass loss signal here. This was shown in a study by Howat et al. (2008), where a higher volume loss was obtained in southeastern Greenland by combining ICESat and ASTER data, compared to only using ICESat data. From this additional knowledge we conclude, that the discrepancies between the modeled and observed uplift are most likely caused by a bias in the mass loss estimate.

At the site THU2 the fit is good at the first time span, but all models fall outside the error bars of the GPS in the last two time spans. This suggests, that the elastic response is not captured completely in the model, at this site. The majority of outlet glaciers along the northwest coast of 
Greenland have widths near the front of less than $7 \mathrm{~km}$ (McFadden et al. 2011), hence the complete mass loss signal might not be captured by the resolution of ICESat, which might explain the under estimation of the modeled elastic uplift in the last two time spans (see Fig. 4).

The agreement in temporal change between the observed and modeled elastic crustal response is a strong indicator of good quality in the modeled elastic response. However, it can not be ruled out that a constant bias is present in the modeled elastic response, e.g. due to sparsely sampled data, which is most likely the case at the site KULU. Based on our results we notice that generally a better fit between modeled and observed crustal displacements is found at sites located relative far from areas with considerable mass loss (e.g. KELY, QAQ1, and SCOR), while a poorer fit is found at KULU (located $90 \mathrm{~km}$ from Helheim glacier, location indicated in Fig. 1) and THU2 (located $20 \mathrm{~km}$ from a smaller glacier). This suggests that the elastic rebound models, derived from ICESat data, captures the main part of the signal well, but miss the very short wavelengths due to the resolution of ICESat.

From analyzing the temporal changes of the observed and modeled elastic uplift we conclude that this approach gives additional information of the validity of the modeled elastic uplift, and hence also in the ability to constrain GIA. Based on the discussion above we find that the sites KELY, QAQ1, and SCOR are suitable for constraining the GIA signal. At these sites, we find the RER + Huy 2 to be the best performing model. At the moment the sites KULU and THU2 are not suitable, probably due to errors in the modeled elastic uplift.

Satellite missions such as CryoSat- 2 and ICESat- 2 will enable us to extend the time series of high resolution elevation changes of the ice sheets. Having longer time series of mass changes will enable us to derive elastic uplift models based on temporal independent data. This will make the method presented here even more applicable in constraining GIA.

Acknowledgements This work was supported by funding from the ice2sea programme from the European Union 7th Framework Programme, grant number 226375. Ice2sea contribution number 080 . This work was partly supported by COST Action ES0701 "Improved Constraints on Models of Glacial Isostatic Adjustment". We thank the Editor-in-Chief Pascal Willis and the three anonymous reviewers for their constructive comments and suggestions, which have helped to improve this manuscript.

\section{References}

Abshire J, Sun X, Riris H, Sirota J, McGarry J, Palm S, Yi D, Liiva P (2005) Geoscience laser altimeter system (GLAS) on the ICESat mission: on-orbit measurement performance. Geophys Res Lett 32:L21S02. doi:10.1029/2005GL024028
Altamimi Z, Collilieux X, Legrand J, Garayt B, Boucher C (2007) ITRF2005: a new release of the international terrestrial reference frame based on time series of station positions and Earth orientation parameters. J Geophys Res 112:B09401. doi:10.1029/2007JB004949

Bevis M, Kendrick R, Smalley R, Dalziel I, Caccamise D, Sasgen I, Helsen M, Taylor F, Zhou H, Brown A et al (2009) Geodetic measurements of vertical crustal velocity in West Antarctica and the implications for ice mass balance. Geochem Geophy Geosy 10:1-11. doi:10.1029/2009GC002642

Chen J, Wilson C, Tapley B (2011) Interannual variability of Greenland ice losses from satellite gravimetry. J Geophys Res 116:B07406. doi:10.1029/2010JB007789

Dziewonski AM, Anderson DL (1981) Preliminary reference Earth model. Phys Earth Planet 25:297-356. http://dx.doi.org/10.1016/ 0031-9201(81)90046-7

Farrell WE (1972) Deformation of the Earth by surface loads. Rev Geophys 10:761-797. doi:10.1029/RG010i003p00761

Fleming K, Lambeck K (2004) Constraints on the Greenland ice sheet since the last glacial maximum from sea-level observations and glacial-rebound models. Quaternary Sci Rev 23:1053-1077. doi:10.1016/j.quascirev.2003.11.001

Howat I, Smith B, Joughin I, Scambos T (2008) Rates of southeast Greenland ice volume loss from combined ICESat and ASTER observations. Geophys Res Lett 35:L17505. doi:10.1029/2008GL034496

Khan S, Wahr J, Leuliette E, van Dam T, Larson K, Francis O (2008) Geodetic measurements of postglacial adjustments in Greenland. J Geophys Res 113:B02402. doi:10.1029/2007JB004956

Khan S, Wahr J, Bevis M, Velicogna I, Kendrick E (2010a) Spread of ice mass loss into northwest Greenland observed by GRACE and GPS. Geophys Res Lett 37:L06501. doi:10.1029/2010GL042460

Khan S, Liu L, Wahr J, Howat I, Joughin I, van Dam T, Fleming K (2010b) GPS measurements of crustal uplift near Jakobshavn Isbræ due to glacial ice mass loss. J Geophys Res 115:B09405. doi:10.1029/2010JB007490

King M, Altamimi Z, Boehm J, Bos M, Dach R, Elosegui P, Fund F, Hernández-Pajares M, Lavallee D, Mendes Cerveira P et al (2010) Improved constraints on models of glacial isostatic adjustment: a review of the contribution of ground-based geodetic observations. Surv Geophys 1-43. doi:10.1007/s10712-010-9100-4

Lucas-Picher P, Nielsen WM, Christensen JH, Adalgeirsdottir G, Mottram R, Simonsen SB (2012) Very high resolution regional climate model simulations over Greenland: identifying added value. J Geophys Res 117:D02108. doi:10.1029/2011JD016267

McFadden E, Howat I, Joughin I, Smith B, Ahn Y (2011) Changes in the dynamics of marine terminating outlet glaciers in west Greenland (2000-2009). J Geophys Res 116:F02022. doi:10.1029/2010JF001757

Peltier W (2004) Global glacial isostasy and the surface of the ice-age Earth: the ICE-5G (VM2) model and GRACE. Annu Rev Earth Planet Sci 32:111-149. doi:10.1146/annurev.earth.32.082503.144359

Schrama E, Wouters B, Vermeersen B (2011) Present day regional mass loss of Greenland observed with satellite gravimetry. Surv Geophys 1-9. doi:10.1007/s10712-011-9113-7

Simpson M, Milne G, Huybrechts P, Long A (2009) Calibrating a glaciological model of the Greenland ice sheet from the last glacial maximum to present-day using field observations of relative sea level and ice extent. Quaternary Sci Rev 28(17):1631-1657. http://dx.doi. org/10.1016/j.quascirev.2009.03.004

Simpson M, Wake L, Milne G, Huybrechts P (2011) The influence of decadal-to millennial-scale ice mass changes on presentday vertical land motion in Greenland: implications for the interpretation of GPS observations. J Geophys Res 116:B02406. doi:10.1029/2010JB007776 
Spada G, Stocchi P (2007) SELEN: a Fortran 90 program for solving the"sea-level equation". Comput Geosci 33(4):538-562. http://dx. doi.org/10.1016/j.cageo.2006.08.006

Spada G, Ruggieri G, Sørensen LS, Nielsen K, Melini D, Colleoni F (2012) Greenland uplift and regional sea level changes from ICESat observations and GIA modelling. Geophys J Int. doi:10.1111/j.1365-246X.2012.05443.x

Sørensen LS, Simonsen SB, Nielsen K, Lucas-Picher P, Spada G, Adalgeirsdottir G, Forsberg R, Hvidberg CS (2011) Mass balance of the Greenland ice sheet (2003-2008) from ICESat data the impact of interpolation, sampling and firn density. Cryosphere 5(1):173-186. doi:10.5194/tc-5-173-2011

Thomas I, King M, Bentley M, Whitehouse P, Penna N, Williams S, Riva R, Lavallee D, Clarke P, King E et al (2011) Widespread low rates of Antarctic glacial isostatic adjustment revealed by GPS observations. Geophys Res Lett 38:L22302. doi:10.1029/2011GL049277

Zumberge J, Heflin M, Jefferson D, Watkins M, Webb F (1997) Precise point positioning for the efficient and robust analysis of GPS data from large networks. J Geophys Res 102(B3):5005-5017. doi:10.1029/96JB03860

Zwally H, Schutz R, Bentley C, Bufton J, Herring T, Minster J, Spinhirne J, Thomas R (2011) GLAS/ICESat L2 Antarctic and Greenland ice sheet altimetry data V031. National Snow and Ice Data Center, Boulder. ftp://n4ft101u.ecs.nasa.gov/SAN/GLAS/ GLA12.031 